
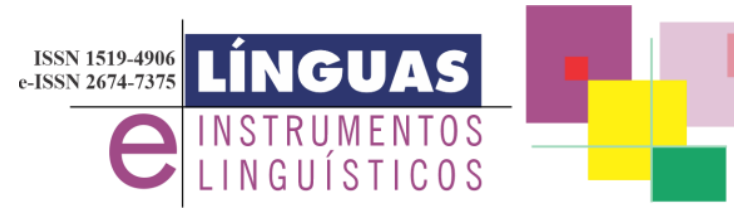

DOI: $10.20396 /$ lil.v24i47.8667089

\title{
DOSSIE
}

\section{Conhecimentos linguísticos e processos de urbanização}

A proposta deste dossiê foi reunir artigos que considerassem de algum modo a historicidade dos conhecimentos linguísticos em suas relações com a cidade, com os processos de urbanização. Um dos eixos que atravessam os textos reside na leitura de arquivo e no modo como ela leva a compreender certos aspectos da produção e circulação de conhecimentos em diferentes materiais e conjunturas. São revistas científicas que acumulam e organizam saberes, leituras de acervos que abrigam textos de autores, instituições que fundam discursividades científicas, disciplinas que observam ou são afetadas pela urbanidade, vozes comunitárias em canções e arquivo de língua falada, dicionários projetam subjetividades no território nacional, propostas de ensino que significam sujeitos da escolarização.

Abrindo o dossiê, Vinícius M. Castro realiza um percurso de leitura de artigos das 47 edições da revista Línguas e Instrumentos Linguísticos, publicada desde 1998, buscando os indícios que sinalizam a produção de saberes urbanos em meio a saberes linguísticos. São considerados autores e temas que trazem à tona questões urbanas e citadinas, perspectivas teóricas, análises e ainda atividades de projetos, formação de pesquisadores e criação de laboratórios de pesquisa. Notase aí a importância dos periódicos na história das ideias linguísticas e mais especificamente na formação de uma área de pesquisa como a de Saber Urbano e Linguagem.

Com a utilização de uma ferramenta de "textometria" de acesso aberto (AFC - Análise Fatorial de Correspondências), que indica frequências, "concorrências", "nós" e "nuvens" de palavras, Mariana G. de Castro Alves analisa quatro textos de Eni Orlandi dos anos 2010, mostrando sentidos de palavras e relações com noções inovadoras como 
"ordem e organização da cidade", "tópica cívica", "narratividade", "processos identitários", dentre outras. Não se detendo nas facilidades técnicas nem às aversões às ferramentas, a autora invoca uma "leitura não-subjetiva, cara à história da AD" e busca "ultrapassar as evidências subjetivas de leitura, no processo de interpretação do arquivo". Tais análises levam a refletir sobre a autoria na abordagem discursiva da cidade, com base na textualidade observada pelo instrumento e pelas questões que surgem dessa leitura.

Em seu texto, Dantielli A. Garcia aborda o processo de institucionalização de um saber linguístico no Instituto Histórico e Geográfico Brasileiro. Para isso, analisa discursos fundadores, a documentação de saberes na Revista do IHGB e um texto de Vanhagen (Memória sobre a necessidade do estudo e do ensino das línguas indígenas do Brasil, de 1841). Observando os saberes linguísticos, Garcia propõe uma distinção de domínios: letra, palavra, comentário linguístico, instrumento linguístico e teorias. Um dos pontos ressaltados na análise é o discurso civilizatório que ressoa e projeta sentidos para a produção de conhecimentos sobre as línguas, o que leva a atentar para certos sentidos que serão em seguida atribuídos à urbanidade.

Retornando ao Dicionário de Vocábulos Brasileiros, de Robepaire Rohan, no final do século XIX, José H. Nunes analisa o discurso lexicográfico no momento de implantação da República. O questionamento de procedimentos de análise, de seus limites e possibilidades, conduz à análise de sujeitos ligados à espacialidade do território: às "províncias", ao campo, à cidade, às minas, aos refúgios, aos sertões, às montanhas, aos espaços urbanos. A análise suscita o debate sobre as contradições dos discursos dominantes na relação com sujeitos e espaços que divergem da organização estatal e demandam sentidos diante das transformações advindas com a República.

Trazendo uma reflexão sobre a abordagem de canções populares, Pedro de Souza discute a "variação linguística", considerando as variantes da língua oral, a enunciação como acontecimento, a voz, as práticas culturais, o cotidiano, a relação com o político. Nessa direção, tem em vista singularidades no modo de falar, seja na cidade, no campo ou na circulação das canções de uma região a outra. Para a discussão teórica da variação, considera a sociolinguística (Dino Pretti, Labov), estudos de enunciação (Emile Benveniste), a pragmática (Giles 
Deleuze) e estudos da canção por Luiz Tatit. Passando por Dorival Caymmi, Noel Rosa, Paulo César Pinheiro, Baden Powell, Elis Regina, Lupcínio Rodrigues, Adoniran Barbosa, Pedro de Souza acena para uma investigação da voz como uma modalidade de arquivo da história do português falado.

Com base na História das Ideias Linguísticas e na Análise de Discurso, Marisa Vieira apresenta uma análise de Parâmetros Curriculares Nacionais de Língua Portuguesa de $5^{\mathrm{a}}$ a $8^{\mathrm{a}}$ séries $(\mathrm{PCN})$, mostrando também como os sentidos ali produzidos ressoam em verbetes do Grande Dicionário Houaiss (online). Há uma memória discursiva das práticas escolares e de políticas linguísticas, marcada por palavras como conversão, regeneração e mais recentemente adequação. No século XIX e início do XX, em um período de crescimento das cidades, faltaram políticas públicas de integração dos escravos libertos. Com isso, o discurso religioso deslocou-se para um discurso jurídico-moralizante e posteriormente para um discurso tecnicista de adequação. A análise dos PCNs e em seguida do Houaiss explicita uma rede de palavras e sentidos dessa "adequação" (ajustamento, acomodação, conformidade, desinteligência), que circulam nas últimas décadas da história da alfabetização no Brasil.

Por fim, agradecemos imensamente aos autores que, diante da pandemia do coronavírus e de outras instabilidades, aceitaram participar deste dossiê. E desejamos que a publicação desperte indagações sobre o que é dito ou não a respeito da cidade, do urbano, na relação com a história dos saberes linguísticos. Entre a familiaridade e a estranheza que essa conexão suscita, algumas trilhas e pistas se abrem, se entrecruzam e propiciam outras incursões.

José Horta Nunes

Organizador 